\title{
Purification of air on pig-rearing farms
}

Gladiy M. ${ }^{1}$, Voloshchuk V. ${ }^{2}$, Smyslov S. ${ }^{3}$, Zasu-kha L. ${ }^{4}$

${ }^{1}$ National academy of agrarian sciences of Ukraine, Mykhailo Omelianovych-Pavlenko Str., 9, Kyiv, 01010, Ukraine, ${ }^{2-4}$ Institute of swine breeding and agroindustrial production of NAAS, Shedska mohyla Str., 1, Poltava, 36013, Ukraine; e-mail: ${ }^{1}$ prezid@naas.gov.ua, ${ }^{2-4}$ pigbreeding@ukr.net

The purpose. To determine extent of completeness of purification of air and fitness of the developed experimental samples of chamber to their application for decreasing content of polluting gases at air removal from rooms of industrial complex. Methods. Measurement of the content of polluting gases in air before and after passage of air through the chamber of purification. Tests were led in department of fattening pigs of "AgroPrime Holding Ltd.» (Karakurt, Bolgrad region, Odesa oblast). Level of concentration of ammonia and hydrogen sulfide was logged by means of certificated and believed device: multicomponent individual warning device-analyzer of gases «Dozor-S-M». Results. It was established that the level of hydrogen sulfide in air of room at altitude of $0,5 \mathrm{~m}$ from floor made $3,34 \mathrm{mg} / \mathrm{m} 3$, above manure bath $-9,72$, on an entry in the upper filter from below $-2,46$, on an entry in the upper filter sideways $-3,03$, on an exit of stack of exchange of air on roof $-2,83$, and on an entry in the side filter $-5,66 \mathrm{mg} / \mathrm{m} 3$. Level of ammonia at altitude of $0,5 \mathrm{~m}$ from floor made $1,84 \mathrm{mg} / \mathrm{m} 3$, above manure bath $-5,28$, on an entry in the upper filter from below $-1,34$, on an entry in the upper filter sideways $-1,64$, on an exit of stack of exchange of air on roof $-1,54$, on an entry in the side filter $-3,08 \mathrm{mg} / \mathrm{m} 3$. Hydrogen sulfide and ammonia were not revealed on an exit from air channels with chambers for air filtration. Conclusions. The gained results testify to the following: during tests the air, polluted by stinking gases, after chamber of purification was completely freed from gases. They did not fix both by devices or organoleptically presence of ammonia and hydrogen sulfide. Purification of contaminated air of rooms by means of the developed chamber enables completely delete ammonia and hydrogen sulfide. So, it is possible to ventilate rooms without environmental pollution.

Key words: technology of growing, air pollution, hydrogen sulfide, ammonia, purification of air, sanitarian state of environment.

https://doi.org/10.31073/agrovisnyk201811-13

Formulation of the problem. The development of pig breeding and the concentration of livestock on industrial complexes raises a number of problems related to the environmental impact. According to the standards of technological design [1], for enterprises on the production of pig breeding products it is stipulated the minimum distances from settlements in order to reduce the distribution of unpleasant smells to the residential area.

Polluting environmental gases $\left(\mathrm{H}_{2} \mathrm{~S}\right.$ and $\left.\mathrm{NH}_{3}\right)$ are largely removed from the premises during ventilation, as well as a significant amount of them is eliminated into air from the manure settlers, or when separating the manure for liquid and solid fractions.

If the section of separating manure occupies an insignificant area and can be covered with a "sarcophagus", then air from the pig breeding premises is removed both through the roof and wall ventilation openings, and therefore the polluting gases enter into air almost throughout the pig farms.

Analysis of recent researches and publications. In recent decades there has been the global environmental pollution with organic compounds, micro-and macroorganisms, the source of which are large pig complexes. The spectrum of polluting with the products of activity of pig complexes is rather large, that is atmospheric air, soil, surface water and ground water. According to Belarusian scientists, the pig complex for 108 thousands of pigs throws into the atmosphere for 1 hour $56 \mathrm{~kg}$ of ammonia and $15-20 \mathrm{~kg}$ of dust, unpleasant smell spread to a distance to $5 \mathrm{~km}$. In the summertime, during the windless weather near the pig complex for 54 thousands of pigs, it is determined a high bacterial air pollution at a 
distance of up to $500 \mathrm{~m}$, and 136 names of gases are emitted from pig farms, among them hydrogen sulfide, ammonia and carbon dioxide are the most toxic[2, 6, 7].

Given the high polluting role of pig complexes, today there is a problem with improved pork production technologies from the standpoint of environmental safety. The environmental safety of the environment is achieved by developing the necessary equipment and by creating an appropriate microclimate in the premises by means of effective air purification both in the area of animal housing and air that is removed from the premises $[4,5]$.

This problem can be solved by the use of ventilators equipped with new means of purification of polluted air. Such means include mechanical purification, ozonation, aerosolization, and utilization of exhaust gases in greenhouses for foliar and root nutrition $[3,8,9,10]$.

But each of these technologies has both positive and negative sides. Therefore, on the basis of the above arguments, the development of appropriate equipment for the purification of polluted air, the creation of an ecologically safe environment around the pig farms is one of the important modern problems.

Purpose and tasks. The purpose of the researches was to determine the degree of suitability of the developed experimental models of a chamber for use in an industrial complex for cleaning the removed air from the premise. To perform the task, it was made the several measurements of indexes on the content of polluting gases in air of the premises where the fattening pigs are housed, as well as at the exit from the premise through the roof and side ventilation openings without cleaning and at the exit from the ventilation openings after air passing through cleaning chamber.

Research results and their discussion. On the base of the pig fattening workshop of Ltd "AgroPrime Holding" it has been conducted the instrumental tests of the degree of purification of intracorporeal air at using experimental samples of air purification chambers (lateral and upper), Fig. 1, 2, in v. Karakurt, Bolgrad district in Odessa region.
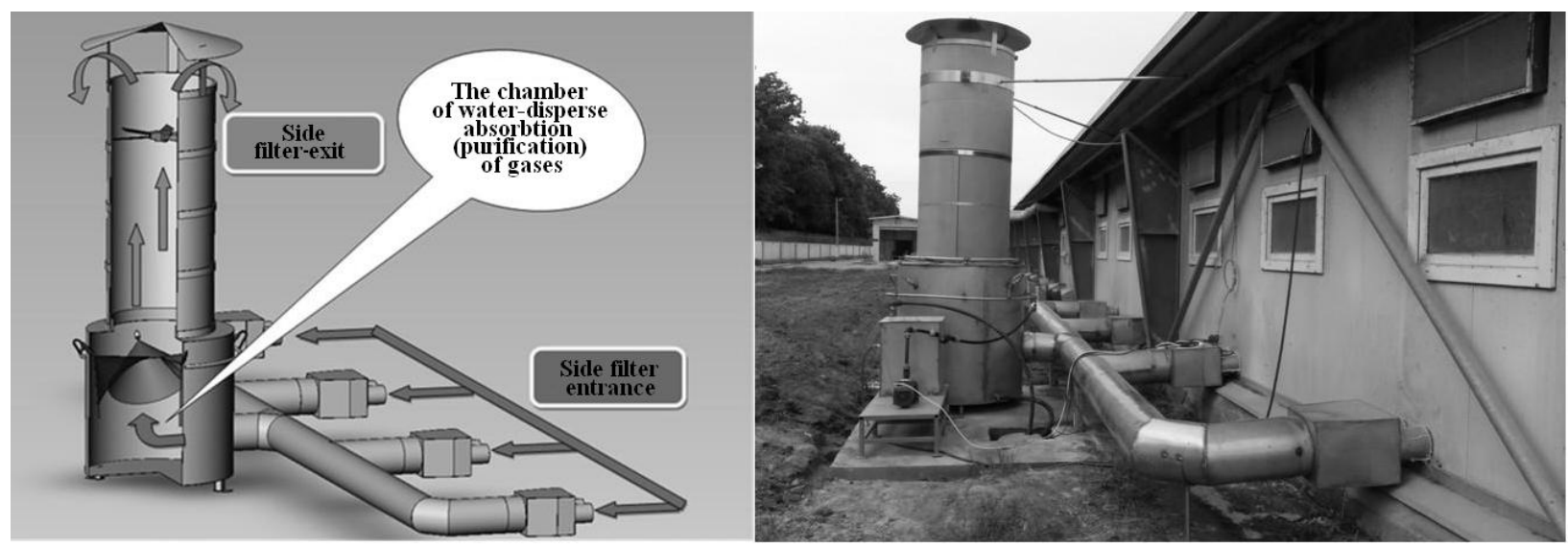

Fig. 1. Design sketch (at the left) and exterior (at the right) of the side air purification chamber

The level of concentration of ammonia and hydrogen sulfide was registered with the help of a certified and authorized device: a multi-component individual gas signalizer-analyzer "DOSOR-S-M".

The hygienic parameters of microclimate in the premise of the fattening shop were fixed with the help of four sensors of the "Electronic analyzer of microclimate" EAM- 5 spaced across the entire space and during the tests indicated the following parameters: air temperature $20.9 \mathrm{C}$, atmospheric pressure 754.8 mm.Hg.c., relative humidity $64.3 \%$. 

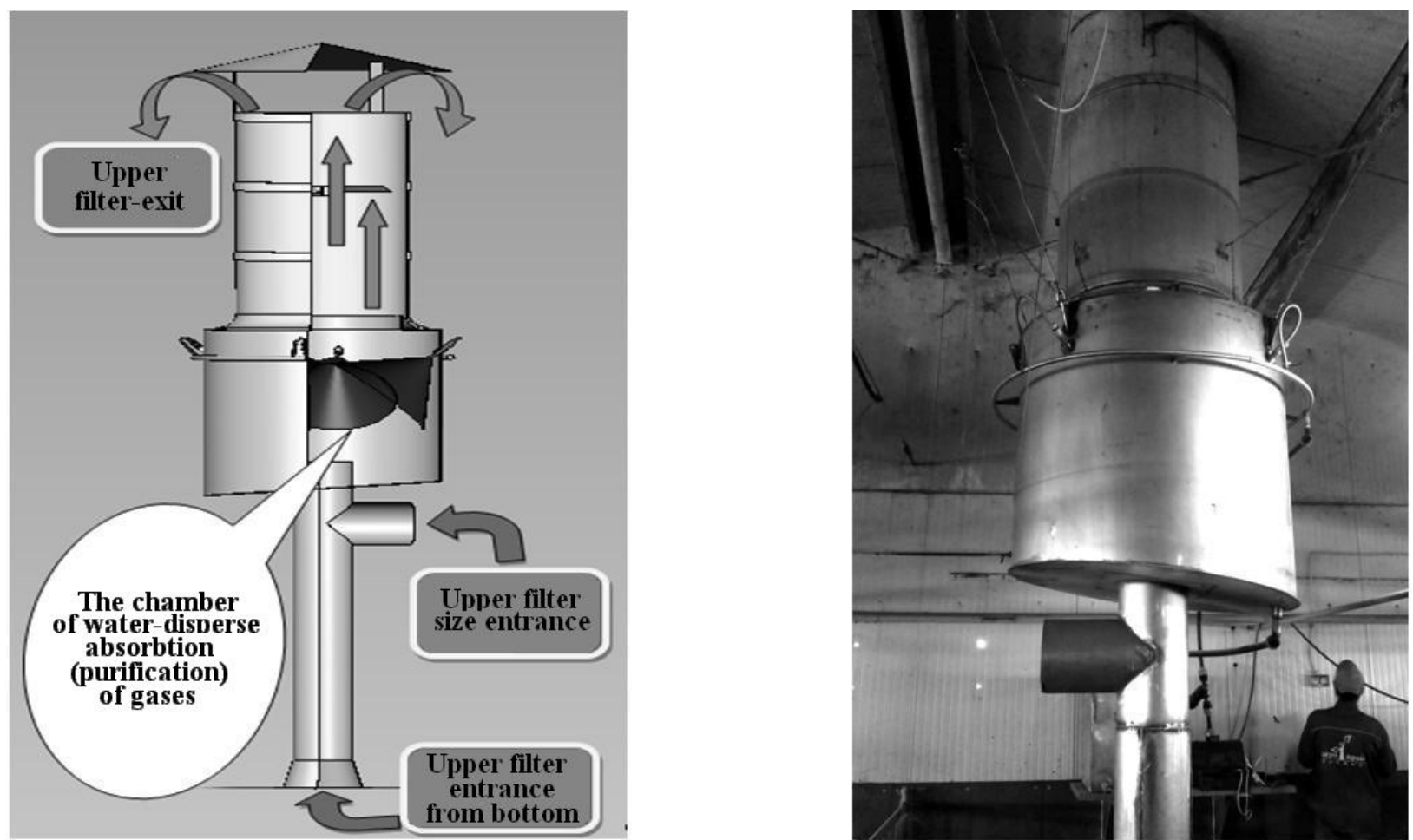

Fig. 2. Design sketch (at the left) and exterior (at the right) of the upper air purification chamber

The scheme of sampling air with the indication of control points is shown in Fig. 3.

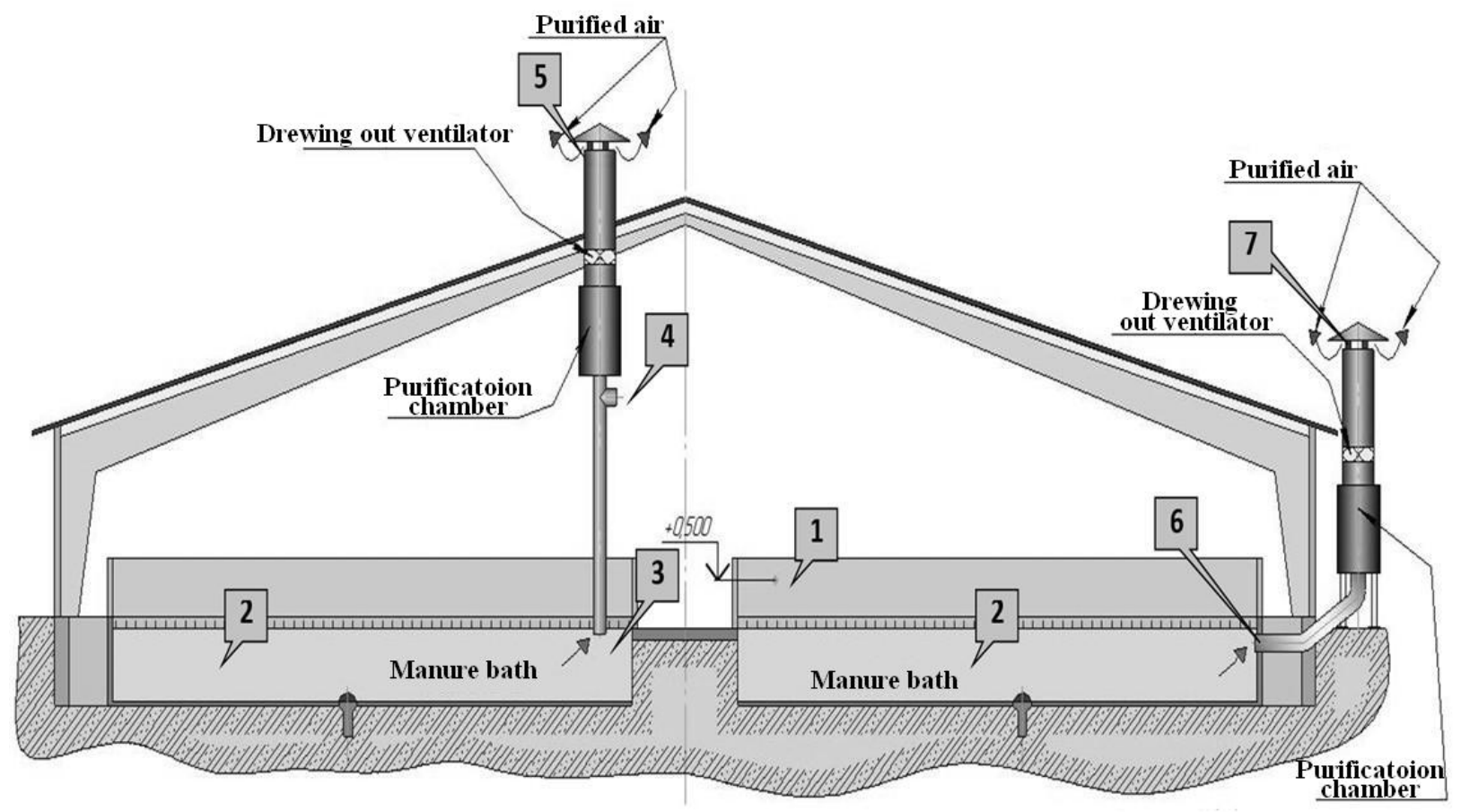

Fig. 3. Control points for measuring the concentration of toxic smelge gases on the sketch of the installation of air purification chambers

1. At a level of $0.5 \mathrm{~m}$ from the floor; 2 . At the top of the manure bath; 3. Upper filter (entrance from below); 4. Upper filter (entrance to the side);5. Upper filter (exit); 6. Side filter (entrance); 7. Side filter (exit). 
The analysis of the results showed that one of the most toxic and odorous gases that are formed during the life of pigs, namely hydrogen sulfide (H2S), was present in premises at a sufficiently high concentration. The analysis of literary data shows that the hydrogen sulphide odor of "rotten eggs" is strongly expressed already at $3.3 \mathrm{mg} / \mathrm{m}$ and at concentrations of more than $4-7 \mathrm{mg} / \mathrm{m}$ becomes unbearable. Organoleptically, it is felt in concentrations ten times lower.

In the premise at a maximum allowable concentration of $10 \mathrm{mg} / \mathrm{m}$, it was recorded in air at different levels of the pig-breeding premise in rather wide limits: at a height of $0.5 \mathrm{~m}$ from the floor $-3.34 \mathrm{mg} / \mathrm{m}$, above the manure bath $-9.72 \mathrm{mg} / \mathrm{m}$, at the entrance to the upper filter bottom $-2.46 \mathrm{mg} / \mathrm{m}$, at the entrance to the upper side filter $-3,03 \mathrm{mg} / \mathrm{m}$, at the exit of the roof air exchange mines $-2.83 \mathrm{mg} / \mathrm{m}$, at the entrance to the side filter $-5.66 \mathrm{mg} / \mathrm{m}$.

The next of the irritant-poisonous gases - ammonia (NH3), was registered in much smaller quantities. Nevertheless, its concentration varied in control points of measurements in wide limits: the level of $0.5 \mathrm{~m}$ from the floor $-1.84 \mathrm{mg} / \mathrm{m}$, air above the manure bath $-5.28 \mathrm{mg} / \mathrm{m}$, the entrance to the upper filter bottom $-1.34 \mathrm{mg} / \mathrm{m}$, entrance to the upper filter side $-1,64 \mathrm{mg} / \mathrm{m}$, the exit of the ventilation mine on the roof $-1,54 \mathrm{mg} / \mathrm{m}$, at the entrance to the side filter $-3,08 \mathrm{mg} / \mathrm{m}$. At the maximum permissible concentration of $20 \mathrm{mg} / \mathrm{m}$, the levels found are less important components in the formation of spill gases in the internal air, and subsequently from emissions from pig farms. However, the synergism of the enriching effect of the mixture of these two gases has been noted for a long time.

The presence of ammonia and hydrogen sulfide before and after air purification clearly is showed in the following graph, Fig. 4

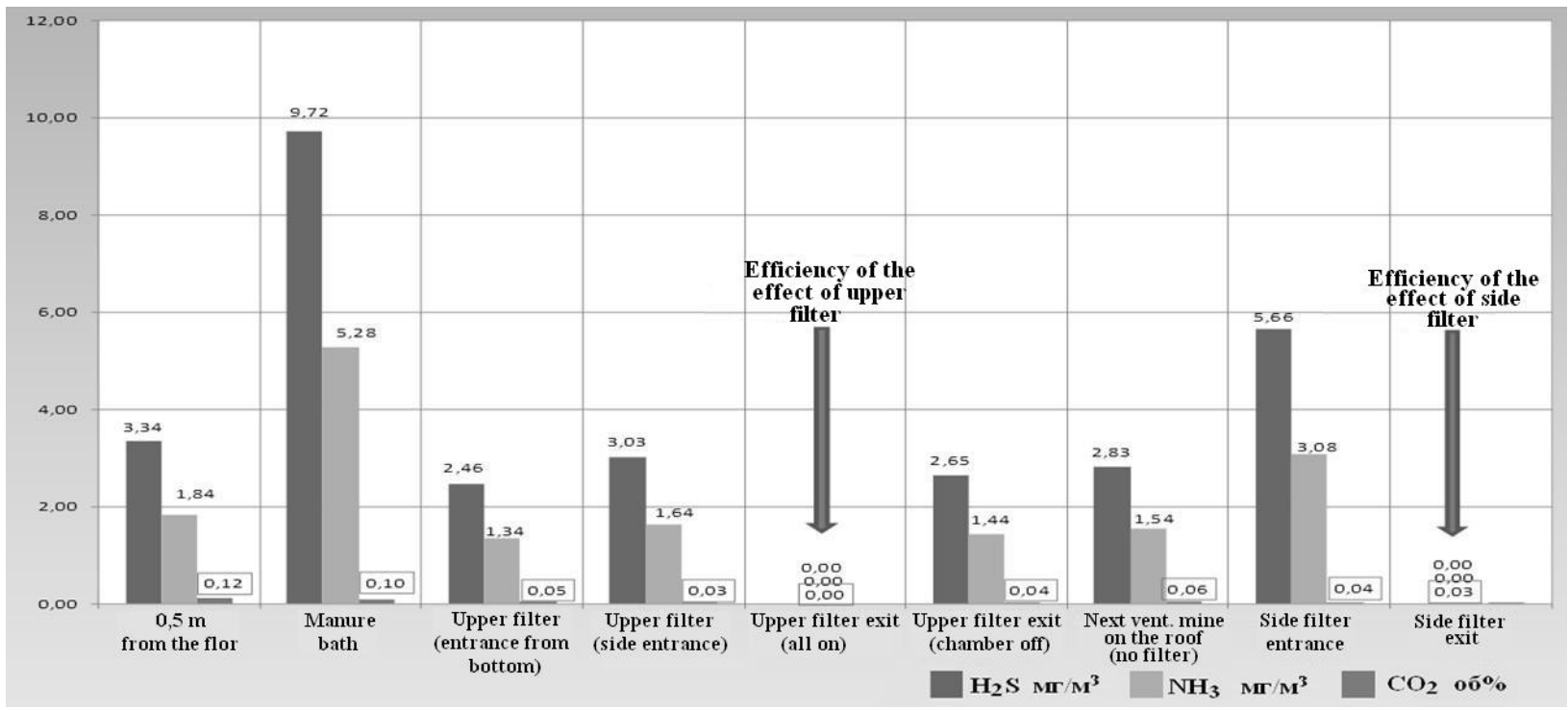

Fig. 4. Graphical and numerical values of the presence and concentration of gases at different points of the survey

Regarding carbon dioxide (CO2), on the one hand its level was very small (range from $0.12 \mathrm{vol} \%$ to $0.03 \mathrm{vol} \%$ ), but on the other hand it is a gas without odor and is not a problem in the formation of the spectrum of endogenous emissions. Statistically processed indexes of the concentration of harmful toxic gases are given in Table. 1 
Table 1. Quantitative indexes of a level of toxic gases in different measuring points

\begin{tabular}{|l|c|c|c|}
\hline \multicolumn{1}{|c|}{ Measurement control points } & $\begin{array}{c}\mathrm{CO}_{2} \\
\text { об } \%\end{array}$ & $\begin{array}{c}\mathrm{H}_{2} \mathrm{~S} \\
\mathrm{mg} / \mathrm{m}^{3}\end{array}$ & $\mathrm{NH}_{3} \mathrm{mg} / \mathrm{m}^{3}$ \\
\hline 0.5 m from the floor & $0,12 \pm 0,08$ & $3,34 \pm 0,24$ & $1,84 \pm 0,13$ \\
\hline Manure bath & $0,10 \pm 0,002$ & $9,72 \pm 0,93$ & $5,28 \pm 0,51$ \\
\hline Upper filter (entrance from bottom) & $0,047 \pm 0,00$ & $2,46 \pm 0,18$ & $1,34 \pm 0,10$ \\
\hline Upper filter (side entrance) & $0,03 \pm 0,003$ & $3,03 \pm 0,16$ & $1,64 \pm 0,08$ \\
\hline Upper filter (exit (all on) & 0,00 & 0,00 & 0,00 \\
\hline Upper filter (exit (chamber off) & $0,04 \pm 0,001$ & $2,65 \pm 0,15$ & $1,44 \pm 0,08$ \\
\hline Next vent. mine on the roof (no filter) & $0,06 \pm 0,00$ & $2,83 \pm 0,04$ & $1,54 \pm 0,02$ \\
\hline Side filter (entrance) & $0,04 \pm 0,00$ & $5,66 \pm 0,20$ & $3,08 \pm 0,11$ \\
\hline Side filter (exit) & 0,00 & 0,00 & $0,03 \pm 0,00$ \\
\hline
\end{tabular}

The most significant measurements of the concentration of gases at the exit of filters have been found to evaluate the effectiveness of the air purification chamber (water-dispersed filter-absorber). First, at the exit of the upper filter (on the roof), the level of all detected gases was below the sensitivity limit of the device "DOSOR-S-M", and the indication was "zero" on the monitor. At measurements at the same control point with the excluded purification chamber $2,65 \mathrm{mg} / \mathrm{m}$ of hydrogen sulfide, $1,44 \mathrm{mg} / \mathrm{m}$ of ammonia and $0,04 \%$ of carbon dioxide were detected. Measurements from the adjacent ventilation mine (where air from the premises was removed without a filter) found $2.83 \mathrm{mg} / \mathrm{m}$ of hydrogen sulfide, 1.54 $\mathrm{mg} / \mathrm{m}$ of ammonia and $0.06 \%$ of carbon dioxide.

Hydrogen sulfide and ammonia at the output of air from the side filter with the switched on air purification chamber are also not registered, although there are only trace amounts $(0.03 \%$ by volume $)$ of carbon dioxide, although the input was $5.66 \mathrm{mg} / \mathrm{m}\left(\mathrm{H}_{2} \mathrm{~S}\right)$ and $3.08 \mathrm{mg} / \mathrm{m}\left(\mathrm{NH}_{3}\right)$.

\section{Conclusions and perspectives of further searches in this direction}

When the levels of toxic gases of hydrogen sulfide $\left(\mathrm{H}_{2} \mathrm{~S}\right)$ and ammonia $\left(\mathrm{NH}_{3}\right)$ registered at the input levels are checked, under the appropriate seasonal climatic conditions the air purification chambers (water-dispersed filters-absorbers) carries out a full one hundred percent air purification that is removed from the pig farms .

The removal of air from the premises through the purification chamber makes it practically impossible to pollute the environment by products of animal life as a result of its complete purification.

The continuation of researches in the search for the possibility of thorough cleaning removed air from the livestock premises of and the development of compact devices that would effectively carry out the purification is perspective and necessary, as the environmental situation deteriorates annually and the pollution of the environment increases with products of animal life in industrial complexes.

\section{References}

1. Vidomchi normy tekhnolohichnoho proektuvannia. Svynarski pidpryiemstva (kompleksy, fermy, mali fermy). [Departmental standards of technological design. Pig farms (complexes, farms, small farms)]: VNTP-APK-02.05. Kyiv: Minahropolityky, 2005. 98 p. [In Ukrainian].

2. Bezmen V.A., Perashvili I.I., SHevchuk N.A. i dr. (2009). Zoogigiyenicheskaya otsenka opytnogo obraztsa ustanovki ochistki vozdukha ot vrednykh gazov UOVS-10. [Zoohygienic evaluation of the prototype of the air purification system for harmful gases UOVS-10]. Zootekhnicheskaya nauka Belarusi, No 1(44). P. 201 - 207. [In Russian].

3. Gordeev V.V., Gordeeva T.I. (2013). Intensivnye tekhnologii v zhivotnovodstve i obespechenie ehkologicheskikh trebovaniy. [Intensive technologies in livestock and environmental requirements]. Vestnik VNIIMZH. No 4(12). P. 159 - 153. [In Russian]. 
4. Kosandrovich E.G., Soldatov V.S. (2004). Sorbtsiya ammiaka iz vozdukha voloknistym sul'fokationitom FIBAN K - 1. [Sorption of ammonia from the air by fibrous sulfonic cation exchanger FIBAN K - 1]. Vestsi NAN Belarusi: ser. khim. navuk. No 3. P. 95 - 98. [In Russian].

5. Voloshchuk V.M. (2014). Problemy soderzhaniya pogolov'ya zhivotnykh raznykh vidov pri organizatsii raboty VIP-ferm. [Problems of maintenance of livestock of animals of different species in the organization of work of VIP farms]. Zootekhniya. No 4. P. 18 - 20. [In Russian].

6. Voloshchuk V.M., Pidtereba O.I., Zasukha L.V. (2017). Osoblyvosti utrymannia riznovydovoho poholivia tvaryn na malykh fermakh. [Features of the maintenance of a variety of animals in small farms]. Visnyk Sumskoho Natsionalnoho ahrarnoho universytetu. Seriia «Tvarynnytstvo». Sumy, Vyp. 5/2 (32). P. 31 - 37. [In Ukrainian].

7. Vozmilov A.G., Andreev L.N. (2016). Ehnergoehffektivnye tekhnologii mikroklimata v zhivotnovodstve. [Energy efficient microclimate technologies in animal husbandry]. Veterinariya. No 1. P. 12 - 17. [In Russian].

8. Ladygichev M.G., Berner G.YA. (2004). Zarubezhnoe i otechestvennoe oborudovanie dlya ochistki gazov: Spravochnoe izdanie. [Foreign and domestic equipment for gas cleaning: Reference Edition]. Moskva: Teplotekhnika. 696 p. [In Russian].

9. Smolin N.I., Zherebtsov B.V. (2018). Sushchestvuyushchie metody i tekhnicheskie sredstva ochistki vozdukha ot serovodoroda. [Existing methods and technical means of air purification from hydrogen sulfide]. Ehlektronnyy nauchno-prakticheskiy zhurnal "Sovremennaya tekhnika i tekhnologii». 5 p. [In Russian].

10. Tolochko A.I., Filippov V.I., Filip 'ev O.V. (1982). Ochistka tekhnologicheskikh gazov v chernoy metallurgii. [Purification of process gases in the steel industry]. Moskva: Metallurgiya, 277 p. [In Russian]. 